Đorđe Božović

\title{
ARTIKULACIONE BAZE U KONTAKTU: SOCIOFONOLOŠKI ASPEKTI
}

\begin{abstract}
Osobine govornih segmenata i elementi prozodije $u$ albanskom jeziku posmatraju se u radu u arealnom kontekstu, pre svega u poređenju sa štokavskom akcentuacijom i srodnim pojavama u štokavskim govorima, sa kojima, u određenim aspektima, dele niz zajedničkih arealnih obeležja, čije izoglose presecaju i podvajaju jezike tradicionalno shvaćenog balkanskog saveza.
\end{abstract}

Ključne reči: palatalne afrikate, glotalni frikativ, retrakcija akcenta, kvantitet i kvalitet vokala, albanski jezik, balkanski jezički savez.

\section{Uvod}

U albanskome su veoma dobro posvedočeni različiti jezički kontakti na Balkanu, od antike do savremenog doba. Albanski jezik je u nekoliko talasa bio izložen ekstenzivnoj romanizaciji, kao i kontaktima s grčkim jezikom, a od srednjega veka je u bliskim etnolingvističkim vezama s južnoslovenskim jezicima i, kasnije, sa turskim (Demiraj 1989: 105-130). Albanski, otuda, predstavlja i jedan od centralnih jezika balkanskog jezičkog saveza (Çabej 1987; Ismajli 2012), iako nisu svi balkanizmi - fonološki, gramatički, leksički i frazeološki - jednako zastupljeni u obama njegovim dijalektima. Južni ili toskijski dijalekat albanskoga više je balkanizovan od severnoga, gegijskog dijalekta; tj. i u fonološkom, i u gramatičkom pogledu, arealno se približava makedonskome i drugim centralnim jezicima balkanskoga jezičkog saveza, za razliku od gegijskoga, koji je po tome arealno bliži susednim štokavskim dijalektima, o čemu će i ovde u radu biti više reči iz fonološke perspektive.

1 Studentski trg 3, Beograd, djordje.bozovic@fil.bg.ac.rs 
Dijalekatsko raslojavanje albanskoga jezika na dva velika narečja, severno i južno, prethodi dolasku Slovena na Balkan, budući da karakteristične dijalekatske glasovne promene u toskijskome, rotacizam $n>r$ uz denazalizaciju vokala, prema očuvanome međuvokalskom $n$ i fonološkim opozicijama po dužini i nazalizovanosti kod vokala u gegijskome, nisu sprovedene u kasnijim pozajmljenicama, slavizmima i turcizmima u albanskom jeziku, već se njihovi refleksi pojavljuju u autohtonom leksičkom fondu i starijim grecizmima i latinizmima. Uz njih, snopu fonoloških izoglosa koje razdvajaju albanska narečja pridružuju se i inicijalna grupa vo- na severu : $v a$ - na jugu, diftong ue na severu, ukoliko nije monoftongizovan : ua na jugu, $n j, q, g j>j$ u međuvokalskom i finalnom položaju na severu : $n j, q$, gj na jugu, opozicija po zvučnosti kod opstruenata i u kodi na severu, prema desonorizaciji na jugu, prelaz finalnog $h>f$ i konsonantski klaster $h t>f t$ na severu : $h, h t$ u toskijskim govorima, te retrakcija akcenta s otvorene ultime u turcizmima u gegijskome (káfe, bábë bá:b), prema oksitonezi na jugu (kafé 'kafa', babá 'otac'); dok refleksi konsonantskih grupa $k l, g l, t j, d j$ i palatala $q, g j$, kao i artikulacija palatalnih afrikata $c ̧, x h$, prenazalizovanih ploziva $m b, n d, n g j, n g$ i glotalnog fikativa $h$, te refleksi laterala $l \mathrm{u}$ konsonantskim grupama $p l, b l, f l$, uz delabijalizaciju vokala $y$, $o$ i labijalizacije vokala $i, e, a$, različite vokalske redukcije ili poziciona duljenja, kao i monoftongizacije diftonga ie, ye, ue ua ili diftongizacije monoftonga, u različitima arealima $\mathrm{i}$ fonetskim kontekstima divergiraju u gegijskim i toskijskim poddijalektima odnosno grupama govora (cf. Beci 1978; 2002; Desnickaja 1968; Elezović 1949/50; Gjinari 1970; Gjinari \& Shkurtaj 2003: 151-244) - v. i niže.

U velikom delu albanske jezičke oblasti, posebno na severu, prisutni su u značajnoj meri bilingvizam, okaziono i trilingvizam, te diglosija. Iako novije društvenopolitičke prilike u većoj meri doprinose stvaranju monolingvalnih zajednica, istorijski uzajamni albansko-južnoslovenski odnosi predstavljaju jednu od okosnica snažnog bilingvizma i diglosije na albanskom severu, od srednjeg veka do najnovijeg doba (iz referentne literature, cf. Ajeti 1972; Bojović 1991; Curtis 2012; Miklosich 1870; Omari 2012; Popović 1958; Skok 1924; Stanišić 1995). U svakom slučaju, ukupna sociolingvistička situacija na severu albanske, dakle gegijske jezičke oblasti, s dugom istorijom društvenojezičkih kontakata koja je obeležila i poslednji vek, nije bez veze i sa njenim dijalekatskim raslojavanjem; o čemu će nešto više reči, iz arealnolingvističke perspektive, biti i niže u radu. 
ARTIKULACIONE BAZE U KONTAKTU: SOCIOFONOLOŠKI ASPEKTI

\section{Artikulaciona baza}

Osnov svih fonetskih i fonoloških istraživanja svakoga govornog izraza predstavlja artikulaciona baza, sistem automatizovanih artikulacionih navika izvornih govornika datoga jezika. Artikulacionu bazu predstavlja osnovni položaj artikulacionih organa i celokupnost artikulacionih pokreta i izgovornih karakteristika specifičnog jezika, koje svi izvorni govornici usvajaju i automatizuju u ranom detinjstvu kao sistem spontanih izgovornih navika u maternjem jeziku (L1), karakterističnih za konkretni jezički izraz u celini (Bugarski 1996: 125; Kristal 1988: 28; Laver 1978; Malmberg 1974: 76; Miletić 1952: 103). Osnovni izgovorni segment artikulacione baze jeste slog, univerzalna fonetska i fonološka jedinica koja objedinjuje glasovne obrasce u konkretnom jezičkom izrazu i najmanja artikulaciona jedinica, čijim se kombinacijama u govornom nizu konstruišu izgovorne reči, i varijacijama u okviru koje se realizuju suprasegmentna (prozodijska) obeležja govornog niza. Prema tome, osnovu sistema automatizovanih artikulacionih navika izvornih govornika u L1 predstavlja produkcija i organizacija slogova, koji su i domen realizacije svih segmentnih i suprasegmentnih obeležja govornog izraza, kako materijalnih realizacija fonema u artikulacionoj bazi datoga jezika, tako i prozodijskih obeležja jezičkog izraza (Kašić 2000).

Artikulacionu bazu standardnoga albanskog jezika, prema tradicionalnom pristupu fonologiji ovoga jezika (Beci 2004; Dodi 2004), karakteriše 36 fonema. Dijalekatske razlike u odnosu na standard u manjoj meri se tiču fonemskog sastava - gegijskome je poznata i nazalizacija i kvantitet kod vokala kao distinktivno fonološko obeležje, kao i konsonantska fone$\mathrm{ma} / \mathrm{y} /<n g$, ali su mahom potrte razlike između parova palatalnih okluziva $q, g j$ i afrikata $c ̧, x h$, diftonzi ie, ye i ue su uglavnom monoftongizovani tako da se realizuju kao dugi vokali $i:, y$ : u:, okaziono je izgubljena $\mathrm{i}$ fonetska razlika između velarizovanog dentalnog frikativa $d h$ i velarizovanog dentalnog laterala $l l$, a poziciono je izgubljena i fonemičnost glotalnog frikativa $h(>\varnothing, f)$, i sl.; s druge strane, dužina vokala je poznata i govorima južnotoskijskog poddijalekta, dok nazalizovanim visokim i prednjim vokalima u toskijskome odgovaraju nenazalizovani vokali $i, y$ (ako nije delabijalizovano), $e, u$ (gjû $\sim g j u$ 'koleno'), a nevisokim zadnjim $\hat{a}, \hat{o}, \mathrm{i}$ okaziono nevisokom prednjem vokalu $\hat{e}$, odgovara nenazalizovani 
centralni vokal $\ddot{e}$ (vênd vënd 'mesto'; gjâ gjë 'stvar'), dok diftongu ue odgovara diftong ua (grue grua 'žena') i češće se sistemski gubi glotal $h$ u svim pozicijama. U većoj meri se, zapravo, dijalekatske razlike u (mor)fonologiji albanskoga tiču distribucionih karakteristika fonema poput toskijskog rotacizma, koji je u dijahronijskom pogledu povezan sa denazalizacijom i kod vokala (vênë verë 'vino'; rânë rërë 'pesak'), ili promene $n j, q, g j>j$ u finalnoj i međuvokalskoj poziciji (bâj bënj 'činim, radim') u gegijskom dijalektu, odnosno refleksa različitih konsonantskih grupa s palatalizacijom i prenazalizacijom, kao $\mathrm{kl}, \mathrm{gl}, t j, d j \mathrm{i}$ sl. (tosk. klumësht qumësht 'mleko'; geg. tjetër qetër 'drugi'), odnosno $m b \sim m$, $n d \sim n$ i sl. (pas : mbas $\sim$ mas 'posle') itd., neutralizacije obeležja zvučnosti okluziva u kodi u toskijskim govorima ( $i$ madh $\sim i$ math 'veliki'), depalatalizacije $n j>n, q>k$ i sl. ispred prednjeg vokala u gegijskom ( $n j e ̈$ $\sim n i$ 'jedan'; qe $\sim$ kie 'beše'), prelaza $l>j$ iza labijala (fle $\sim$ fje 'spavam' i sl.), te domena različitih morfonoloških alternacija vokala i konsonanata $\mathrm{u}$ fleksiji i derivaciji (poput alternacije $i: u$ u padežnim oblicima određenog vida singulara imenica maskulinuma guturalnih osnova, kao zog- $u \sim z o g-i$ 'ptica'; alternacije $n: \varnothing$ u oblicima singulara indikativa prezenta aktiva, kao bie bjen 'padam' i sl.); - cf. iznad navedenu literaturu.

Eksperimentalna fonetska istraživanja (Moosmüller \& Granser 2006) pokazuju pak da se varijacije u vokalizmu artikulacione baze savremenog albanskog jezika udaljuju u novije vreme od tradicionalne dijalekatske podele, pod uticajem standardnog jezika i sociolingvističkih praksi njegove regionalne aproprijacije. Značajne razlike ne nalaze se danas u velikoj meri između tradicionalnog gegijskog i toskijskog vokalizma, koji podvaja teritoriju Albanije i približava govornike gegijskog dijalekta severne Albanije govornicima gegijskog dijalekta na Kosovu, već značajnije razlike danas leže između artikulacionih baza predstavnika jezičkog standarda na Kosovu i u Albaniji, dok je u samoj Albaniji primećena konvergencija između artikulacionih baza na gegijskoj i na toskijskoj osnovici, tako što obrazovani govornici obaju narečja unose karakteristične odlike drugog dijalekta.

\subsection{Vokalizam i prozodijska obeležja}

Imajući u vidu napred opisane varijacije, u vokalizmu artikulacione baze albanskog jezika nalazi se sedam osnovnih fonema $-i, y, e, \ddot{e}, a, o, u$. Prema kriteriju otvorenosti usne duplje i pokreta tela jezika naviše-naniže, 
visoki odnosno zatvoreni vokali su $i, y, u$, vokali srednje otvorenosti $e, \ddot{e}$, $o$, a nizak odnosno otvoreni vokal $a$. Prema kriteriju položaja tela jezika u odnosu na nepca, pokretima napred-nazad, vokali prednjeg reda jesu $i$, $y, e$, srednjeg je reda (centralizovan) neutralni vokal $\ddot{e}$, zadnjeg su reda $o$, $u$, dok je vokal $a$ fonološki indiferenciran po ovome kriteriju. Uz to, kod vokala zadnjeg reda labijalizovanost je redundantno fonološko obeležje, dok je distinktivna u paru visokih vokala prednjeg reda $i: y$ (Beci, op. cit.: 23-31; Dodi, op. cit.: 37-66).

Pored sedam monoftonga, artikulaciona baza albanskog jezika poznaje i diftonške sekvence koje nastaju na dodiru dvaju osnovnih vokala u hijatu (cf. Beci, op. cit.: 32; Dodi, op. cit.: 70-72). Ti su diftonzi, međutim, pozicione prirode i nemaju fonološku vrednost kao integralne jedinice u sistemu (ibid.). S funkcionalnog aspekta, albanski poseduje jedino morfonološki uslovljene (,,istorijske“") diftonge ie, ye, ue ua $(\sim u o)$ kao morfoneme, koji čine klasu alternanata u određenim morfološkim kategorijama u fleksiji i derivaciji (cf. alternacije $i e: i$ u ndiej 'osećam' : ndihem 'osećam se'; $e$ : ye u kthej 'vratim, okrenem' : kthyer 'vraćeno'; $o:$ ua u dorë 'ruka' : duar 'ruke' i sl.). Svi ovi diftonzi su silaznog karaktera, što znači da nose slogovni akcenat na prvome delu; izuzev diftongoidne sekvence je, koja je u istorijskoj vezi s ie, ali je njihova varijacija nejasna (Orel 2000: 4), i takođe učestvuje u morfonološkim alternacijama (cf. je : $i$ : o u pjek 'pečem' : piqja 'pecijah' : poqa 'pekoh'). Kao takvi, oni predstavljaju poseban slučaj i u sistemu akcentuacije albanskoga, budući da prevlače akcenat dalje za jednu moru od desnog kraja osnove reči, gde on teži da se pozicionira, u skladu sa opštim pravilima albanske prozodije (cf. grúa 'žena' : kuádër 'kadar'; gde se u prvoj reči nalazi „istorijski“, a u drugoj pozicioni fonetski diftong). S druge strane, pojedini inovativniji govori znaju i za sekundarne diftongizacije akcentovanih vokala $i>\ddot{e} i, e$ $>$ ie i dr. (mirë mëir 'dobro'; qe kie 'beše'), ali i tu je reč o poziciono uslovljenim i ograničenim pojavama pre svega distribucionog karaktera (pod akcentom, iza palatala i sl.).

Slogovni akcenat u albanskom jeziku je dinamičkog tipa, senzitivan na morfološki sastav reči i metričku strukturu leksičke (gramatičke) osnove. Akcenat je u reči vezan za pretfinalnu moru osnove, tj. za ultimu osnove ako je ona metrički teška (jaka), bilo da sadrži istorijski dug vokal ili diftong, bilo da je zatvorena konsonantskom kodom; odnosno za penultimu osnove reči, ako je ultima metrički laka (slaba). Svi su flektivni na- 
stavci ekstrametrični, i akcenat reči je paradigmatski nepomičan u fleksiji. Prefiksi takođe ne menjaju akcenatsku strukturu osnove; dok se metrička pravila dodeljivanja slogovnog akcenta ciklički primenjuju iza svake sufiksacije (Bozhoviq 2012; Canalis 2007).

\subsection{Arealni kontekst}

Gegijski dijalekat, kao što je napomenuto, poseduje i kvantitet i nazalizovanost kao distinktivna obeležja kod svih vokala, osim $\ddot{e}$. Minimalni parovi između dugih oralnih i dugih nazalizovanih vokala postoje (me ftue $>$ ftu: 'pozvati' : ftû: 'dunja'), ali su svi nazalizovani vokali redundantno i dugi, a najčešće nose i slogovni akcenat, u čemu se ogleda povezanost obeležja nazalizacije kod vokala u gegijskom sa suprasegmentnom organizacijom govornog niza - kao arealna karakteristika, ona se javlja i u kontaktnim štokavskim govorima zetsko-sandžačkog dijalekta, gde vokalski kvantitet takođe teži redundantnoj nazalizaciji (Stanišić 1995: 49; 2004: 107; v. i tamo citiranu literaturu); dok joj u širem tipološkom i dijahronijskom kontekstu odgovara i paralela s razvojem opšteslovenskih nazalnih vokala (jusova), koja je u vezi s kvantitetskim opozicijama u vokalizmu različitih slovenskih dijalekata (Stanišić 2010: 161).

Pored fonološki dugih vokala u gegijskome, i otvoreni i akcentovani slogovi imaju fonetski bitno duže trajanje od kratkih, zatvorenih i neakcentovanih slogova, ali kraće od sloga s dugim vokalom (shŏk 'drug' : shó $k u$ 'taj drug' : sho:k 'drugovi'). Njihova poludužina, međutim, nema i fonološki status (Ismajli 1975), te je neosnovana tvrdnja o razlikovanju tri stepena dužine vokala u gegijskom dijalektu, kao i teze o arealnom karakteru pretpostavljene gegijske politonije u vezi sa štokavskom prozodijom (Polák 1957; Stanišić 1995: 48; 2004: 106) - v. niže (\$3.2).

Dugi i nazalizovani vokali u gegijskome teže i zatvaranju artikulacije, što vredi i za diftonge ie, ye, ue, koji se monoftongizuju redukcijom nevisokog dela diftonga (diell $\sim$ di:ll 'sunce' i sl.). Zatvaranjem artikulacije dugih i nazalizovanih vokala gotovo se i eliminiše niski dugi nazalizovani vokal $\hat{a}$ u gegijskom $\left(>\hat{a}^{o}, \hat{o}\right)$ - labijalizacija vokala $a$ kao arealno obeležje široko je rasprostranjena i u kontaktnim štokavskim govorima (Stanišić 1995: 50; sa literaturom); a u istom kontekstu se može posmatrati i ikavizam u refleksu dugoga jata u istočnocrnogorskim muslimanskim govorima (Stanišić 1995: 49-50; 2010: 163; v. i tamo navedenu literaturu). 
Artikulacija vokala $y$ izrazito je nestabilna u većini govora, kao što je iznad rečeno, budući da teži delabijalizaciji $y>i$, uz okazionu diftongizaciju $y>e i$ i dalje otvaranje $y>e(y l l \sim e l l$ 'zvezda'); s obzirom na neveliku funkcionalnu opterećenost ove distinkcije u vokalizmu albanskoga jezika. $\mathrm{S}$ druge strane, $\mathrm{u}$ pojedinima inovativnijim govorima, ta je sistemska nestabilnost razrešena funkcionalnim proširenjem opozicije prema labijalizovanosti kod vokala prednjega reda, tako da se ograničeno pojavljuje i labijalizovani parnjak nevisokog vokala prednjeg reda $e: / \varnothing /(v e \sim v / \varnothing /$ 'jaje'), čime se obezbeđuje i simetričnost u vokalskom trouglu albanskoga, a nije nepoznata ni poziciona labijalizacija $i>y$ kraj labijala (kripë $\sim k r y p \ddot{e}$ 'so' i sl.) - s tim u vezi, na stabilnost artikulacije i fonemičnost vokala $y$ u znatnoj meri utiče arealni kontekst, tj. stepen međujezičkih kontakata i interferencije, u prvom redu s turskim jezikom, čiji se vokalizam, zahvaljujući zakonu vokalske harmonije, odlikuje i visoko funkcionalnom opozicijom prema labijalizovanosti. To je i razlog pojave ovoga vokala $i$ u turcizmima u kontaktnim srpskohrvatskim govorima na Kosovu (cf. Remetić 2004; Stanišić 1995: 52; 2005; 2010: 168-169; s tamo navedenom bibliografijom). Prema Stanišiću (2004: 108; 2010: 161-162), tipološki razvoj i ovoga vokala u albanskome (i rumunskome) i opšteslovenskog jerija $(* y)$ u široj arealnoj i dijahronijskoj perspektivi takođe se može posmatrati i u vezi sa nazalizacijom i kvantitetskim opozicijama u vokalizmu.

Pored toga, vrlo je nestabilna i artikulacija centralizovanog vokala srednjeg reda $\ddot{e}(s c h w a)$, koja u različitim govorima ide od poluotvorenog vokala prednjeg reda $[\varepsilon]$ do poluotvorenih vokala srednjega reda [3] i zadnjega reda $[\Lambda]$, dok u otvorenom slogu i u finalnom položaju, kada je nenaglašen, gotovo uvek podleže sinkopi odnosno eliziji s kompenzacionim duljenjem ( $k \ddot{p} p u c \ddot{e}>k p u: c$ 'cipela' i sl.) - cf. kao moguću arealnu i dijahronijsku paralelu reflekse štokavskog poluglasnika $\left(*_{b}\right)$, koji uključuju otvoreni vokal prednjeg reda/æ/ u govorima zetsko-sandžačkog dijalekta, kao i otvoreni vokal srednjeg odnosno zadnjega reda/a/ u ostatku štokavskog narečja; prizrensko-timočki dijalekti čuvaju i refleks tipa schwa; dok su opšteslovenski poluglasnici u tzv. slabom položaju elidirani, uz kompenzaciono duljenje ( $* b r o ̈ d b>b r o ̂ d$ i sl.), što predstavlja i širu tipološku paralelu (Stanišić 1995: 49; 2004: 106-107; 2010: 161, 163). Na sličan način varira i artikulacija niskog vokala $a$, od otvorenog vokala prednjeg reda [æ], do poluotvorenih vokala zadnjeg reda [a] i [p] sa labijalizacijom. 
Nestabilnosti u artikulaciji vokala $\ddot{e}$, međutim, prvenstveno su fonetskog karaktera, dok se u fonološkom smislu tiču jedino distribucionih karakteristika ovoga vokala. On ima znatno rašireniju distribuciju u toskijskom dijalektu, budući da, kao što je rečeno, tu odgovara gegijskim nazalizovanim nevisokim vokalima, primarno zadnjeg odnosno srednjeg reda (Gjinari 1981). Distribucionoga je karaktera i vokalizacija $\ddot{e}>e$ pred sonantima u gegijskom dijalektu (moter motër 'sestra'; $i$ âmel $\sim i$ ëmbël 'sladak'), a kao distribuciona ograničenja, takođe pretežno u gegijskom, treba razumeti i sinkopu i eliziju vokala $\ddot{e}$ u nenaglašenom položaju, ali i generalnu ulogu koju taj vokal ima uz slogovni akcenat u morfonologiji albanskoga, o čemu je više reči dalje u radu (\$3.2) - pretežno gegijska tendencija sužavanja distribucije vokala $\ddot{e}$ može se sagledati i u širem arealnom kontekstu u svetlu konvergencije sa južnoslovenskim dijalektima u kojima ovaj vokal nema fonemski status (Stanišić 1995: 49; 2004: 112); kao posledica sinkope, u gegijskom se javlja i silabičko $r$ (mōtṛs $<$ motrës 'sestri'), koje po Stanišiću (ibid.; 2010: 169) najbližu arealnu paralelu ima upravo u srpskohrvatskome, mada ni ovde, međutim, nije zaista reč o fonološkoj pojavi sensu stricto, već se zapravo radi o fonetskoj, pozicionoj silabičnosti, pa je utoliko i ova arealna paralela u izvesnoj meri upitna, posebno kada se uzme u obzir to što, u kontekstu značajnijeg multilingvizma i međujezičke interferencije, dolazi upravo do gubljenja silabičnosti i fonemičnosti kod ṛ (dekomponovanjem > /ər/) u kontaktnim srpskohrvatskim govorima, kakav je srpski prizrenski govor (ibid.; Remetić, op. cit.; s citiranom literaturom).

\subsection{Konsonantizam}

U konsonantizmu artikulacione baze albanskoga jezika nalazi se oko 29 fonema - imajući u vidu dijalekatske razlike. Seriju ploziva predstavljaju bilabijali $p: b$, dentali odnosno alveolari $t: d$, palatali $q: g j$, i velari $k: g$, kod kojih je distinktivno i obeležje zvučnosti. Seriju nazala čine bilabijal $m$, dental ili alveolar $n$, i palatal $n j$, dok pojedini govori, pretežno gegijski, poznaju i velarni nazal /y/ (uprošćavanjem konsonantskog klastera $<n g$ ). Frikativni konsonanti su labiodentali $f: v$, interdentali $t h: d h$, alveolari $s:$ $z$, palatali $s h: z h$, i glotal $h$, bez parnjaka po zvučnosti. Alveolarne afrikate su $c /$ ts $/: x / \mathrm{dz} /$, a palatalne $c ̧ / \mathrm{t} / \mathrm{x} / x / \mathrm{d} z /$. Albanski razlikuje i dve serije likvida, velarizovani dental $l l \mathrm{i}$ (post)alveolarno $l \mathrm{u}$ seriji laterala, odnosno par rotičkih fonema, alveolarni vibrant $r r$ i alveolarni jednoudarnik $r$. Fo- 
nemski status ima i poluvokal $j$, iako je dosta ograničene distribucije (Beci, op. cit.: 33-44, 103; Dodi, op. cit.: 72-108).

Nestabilnosti u artikulaciji prisutne su u najvećoj meri kod palatalnih konsonanata, afrikata i glotala $h$. Gegijski govori poznaju veća distribuciona ograničenja palatalnih konsonanata, što uključuje depalatalizaciju $n j>n, q>k$ i sl., kao i pozicione promene $n j, q, g j>j$ u međuvokalskom i finalnom položaju. S tim u vezi jesu i nestabilnosti u artikulaciji palatalnih ploziva $q, g j$ i afrikata $c ̧, x h$, koji teže približavanju afrikatskom paru štokavskoga tipa $c$, $đ$ u gegijskim govorima. Slično konfesionalnim markerima u bosanskohercegovačkim govorima (cf. diskusiju u Šipka 1974: 107-112; Peco 1999), i ovde je uklanjanje palatalnih ploziva i nazala iz sistema i umekšavanje artikulacije $c ̧, x h$, uz afrikatizaciju $s h>c ̧, z h>x h$, kao i pomeranje artikulacije lateralnog para $l, l j$ u kontaktnim srpskohrvatskim govorima prema albanskom modelu, u korelaciji s većim stepenom arealne i međujezičke interferencije u opštem sociolingvističkom kontekstu.

Prema Stanišiću (1995: 50-55; 2004: 110-114; 2006; 2007; 2010: 163-168, 170-173; s bibliografijom), severnoalbanski konsonantizam se u ovome pogledu odvaja od kompleksa perifernih srpskohrvatskih i zapadnomakedonskih dijalekata, koje arealno povezuje iščezli slovenski supstrat gegijskoga dijalekta u severnoj Albaniji, dok se u širem kontekstu uklapa i u tipologiju fonoloških sistema balkanskih jezika. Međutim, ovde se radi o relativno skorim tendencijama u konsonantizmu, pa je pitanje u kolikoj meri one odgovaraju supstratskim arealnim odnosima. U tom svetlu, indikativno je da paralele između severnoalbanskog i bosanskohercegovačkog konsonantizma, s druge strane, uključuju i artikulaciju glotala $h$, koji je, opet, u gegijskome očuvaniji nego u južnoalbanskim govorima; osim u kodi, gde je $h>f$ (njoh $\sim$ njof 'znam'). U arealnoj perspektivi, tome odgovara tendencija ka očuvanju artikulacije $h$ i u srpskohrvatskim urbanim varijetetima u ovoj zoni, kao i makedonsko finalno $h>v$ (Stanišić 1995: 55-56; 2010: 169-170). Odnos između čuvanja glotalne artikulacije glasa $h$, urbanizacije i kontakta s turskim jezikom i ovde je, dakle, najbliži onom u bosanskohercegovačkim govorima (cf. Peco 1974: 57-58; kao i iznad citiranu diskusiju). Prema tome, opisane tendencije u konsonantizmu artikulacione baze severnoalbanskih govora, uključujući i njihove razlike u odnosu na kontaktne srpskohrvatske i zapadnomakedonske govore, trebalo bi radije razumeti unutar recentnijeg sociolingvističkog konteksta, kao markere urbaniteta i konfesionalne markere, formirane prema turskom 
jeziku - u tome pogledu, razumljiva je i paralela koju južnoslovenski i gegijski konsonantizam u ovoj zoni, s inače visokim stepenom bilingvizma, imaju upravo u bosanskohercegovačkim govorima. Supstratsko-adstratski arealni odnosi, s druge strane, pre bi se mogli videti u poziciono uslovljenim varijacijama distribucionog karaktera, poput prelaza $l>j(q, g j)$ iza labijala $(p l, b l, f l \sim p j, b j, f j)$ u severnogegijskim i centralnogegijskim govorima, koji jasnu paralelu ima u nejotovanim labijalima, tj. izostanku epentetskog $l$, i u susednim makedonskim i starocrnogorskim govorima, uz „sklonost ka afrikatama“ (Pižurica 1984: 90; Stanišić 1995: 51-52; 2010: 165 sqq.), kao i pojedine druge fonotaktičke i morfonološke paralele.

\section{Prozodijski sistem}

Budući da albanski jezik poznaje samo jednu vrstu slogovnoga akcenta, bez fonoloških razlika u tonalitetu ili trajanju između akcentovanih slogova u različitim pozicijama i rečima, u fonološkom pogledu slogovni akcenat $\mathrm{u}$ albanskome može se smatrati dinamičkim, pre nego tonskim odnosno visinskim, kao što su to, recimo, silazni i uzlazni konturni tonovi u štokavskome. Da albanski akcenat u fonološkom smislu zna samo za jednu, silaznu intonaciju, pokazuju i kontaktni govori zetsko-sandžačkog i kosovsko-resavskog dijalekta sa metataksom i duljenjem kratkog silaznog akcenta, kao i kontaktni prizrensko-timočki govori s duljenjem ekspiratornog akcenta, koji su nesumnjivo posledica bilingvizma (Stanišić 1995: 47-48; 2010: 159-160; v. i tamo navedenu literaturu).

Slično stoji i za mesto akcenta u albanskome. Akcenat u albanskome je, uz malobrojne izuzetke, u pravilu nepokretan u paradigmi i metrički fiksiran na pretfinalnoj mori flektivne osnove reči. I kontaktni govori u zonama s višim stepenom bilingvizma takođe pokazuju da postoji tendencija ka fiksiranju mesta akcenta u albanskome, budući da poznaju karakteristične neetimološke baritoneze (Stanišić, loc. cit.; cf. i Mladenović 2000). Pozicioniranje akcenta u reči u albanskome i susednim južnoslovenskim govorima predstavlja i arealno obeležje koje vredi detaljnije razmotriti (cf. i Ivić 1998a).

\subsection{Baritoneza i paroksitoneza u arealnom kontekstu}

Određeni aspekti akcenatskog sistema albanskoga jezika imaju značajne paralele upravo u susednim južnoslovenskim dijalektima i širem 
arealnom kontekstu. Pre svega je reč o morfološkom fiksiranju akcenta na osnovi reči (baritonezi), tendenciji ka metričkom fiksiranju akcenta na penultimi (paroksitonezi), kao i retrakciji akcenta na penultimu sa otvorene ultime u turcizmima, uz postojanje kvantitetskih opozicija u vokalizmu, u gegijskom dijalektu.

Gledano u arealnom kontekstu, akcenatski sistem albanskoga u celini ulazi u jedan širi fonološki areal u centralnom i zapadnom delu Balkana, koji uključuje i srpskohrvatske dijalekte na severu i severozapadu; pre svega jugozapadne prizrensko-timočke govore, kao i starije i mlađe štokavske dijalekte sa tonskim i kvantitetskim opozicijama u akcentuaciji. Pri tome, gegijski dijalekat albanskoga jezika predstavlja posebnu inovativnu zonu u središtu ovoga areala, koja povezuje jezike tradicionalno shvaćenog balkanskog jezičkoga saveza na jugoistoku sa akcenatski najinovativnijim kompleksom novoštokavskih govora u Bosni i Hercegovini.

Pri tome, važnu i oštru liniju razgraničenja između dva tipa akcenatskih sistema na zapadnom Balkanu predstavlja izoglosa koja razdvaja akcenatske sisteme štokavskih dijalekata s postojanjem tonalnih opozicija od akcenatskih sistema svih jugoistočnijih balkanskih dijalekata, u kojima je slogovni akcenat tzv. dinamičkoga tipa; uključujući prizrensko-timočku dijalekatsku zonu, makedonske govore i albanski jezik. Drugačije se ta izoglosa može razumeti i razlikovanjem mesta akcenta i iktusa (v. način na koji je u okviru istraživanja prizrensko-timočkog akcenatskog sistema formulisana u Alexander 1975: 48-49) - u novoštokavskim dijalektima iktus i akcenat se ne poklapaju nužno na istom slogu, zahvaljujući metatonijskoj retrakciji iktusa na slog pred akcenatskim (tonskim) vrhuncem, što proizvodi disilabičke uzlazne konturne tonove (cf. Babić 1988; Babić \& Josipović 1991; Ivić \& Lehiste 2002; Lehiste \& Ivić 1996); s druge strane, $\mathrm{u}$ dijalektima dalje na jugoistok od novoštokavskih, iktus $\mathrm{i}$ akcenat se $\mathrm{u}$ pravilu redovno poklapaju na istom slogu.

Mada je ovde reč o dvema formulacijama iste pojave, treba primetiti i bitne razlike između njih. Dok prva formulacija, koju nalazimo u tradicionalnoj dijalektologiji i akcentologiji, implicira arhaičnost štokavskih tonskih opozicija prema ekspiratornom akcentu u prizrensko-timočkim dijalektima kao balkanskoj inovaciji, u drugoj je formulaciji fokus upravo na inovativnom karakteru novoštokavske metatonije, u odnosu na konzervativnije akcenatske sisteme s fonološki redundantnim tonalitetom i u dvoakcenatskim govorima zetsko-sandžačkoga i kosovskim govorima 
kosovsko-resavskog dijalekta (cf. Simić \& Ostojić 1996: 136), uz prizrensko-timočke dijalekte i druge balkanske jezike, uključujući albanski, dalje na jugu i istoku.

Pored toga, važnu izoglosu predstavljaju i kvantitetske opozicije u vokalizmu, koje poznaju štokavski dijalekti i gegijski dijalekat albanskoga, kao i neki periferni južnotoskijski govori; dok takve opozicije izostaju u fonološkom sistemu prizrensko-timočke dijalekatske zone i drugih balkanskih jezika dalje na jugoistok, uključujući tu i većinu toskijskih govora albanskog jezika. Prema tome, ova izoglosa je za nas važna i utoliko što predvaja oblast albanskoga jezika na arhaičnije periferije, koje se slažu sa štokavskim dijalektima na severozapadu, i inovativnu centralnu zonu, koja ide skupa s jezicima tradicionalno shvaćenog balkanskog jezičkog saveza (cf. Stanišić 2004: 106; 2010: 160-161).

Kako Stanišić (2004: 110; 2010: 162), međutim, primećuje, postojanje kvantitetskih opozicija nije i jedina arealna paralela albanskoga sa štokavskim vokalizmom; ovamo jednako ide i retrakcija akcenta sa otvorene ultime u turcizmima u gegijskom dijalektu, kao i u makedonskim govorima. Paroksitoneza je i uopšte najprominentnije arealno obeležje koje možemo postupno pratiti na širem terenu centralnog i zapadnog Balkana, počev od albanskoga i makedonskog jezika na jugu, prema prizrensko-timočkim, kosovsko-resavskim, zetsko-sandžačkim i dalje k novoštokavskim dijalektima na severozapadu. Samo, ovde sada nije reč o arhaizmu, već o inovaciji koja povezuje albanski sa celinom štokavskih govora, bez obzira na tonsku i kvantitetsku izoglosu. Albanski jezik u celini u tome pogledu predstavlja jugoistočni ogranak ovoga areala, sa svojim metričkim fiksiranjem akcenta na pretfinalnoj mori osnove, o čemu je iznad bilo reči. Sa zapadnomakedonskim i većinom srpskohrvatskih dijalekata, on čini deo velikog akcenatskog areala na središnjem i zapadnom Balkanu, koji predvaja i jezike tradicionalno shvaćenog balkanskog jezičkog saveza u dve zone (Stanišić, op. cit.).

Paroksitoneza, pri tome, postaje sve slobodnija dalje ka severozapadu. I u samom albanskome; dok je u toskijskom ona ograničena metrički na pretfinalnu moru osnove, u gegijskom joj možemo pridružiti i pomenutu retrakciju akcenta s otvorene ultime. Zapadnomakedonski govori, poput albanskoga, periferno se pridružuju ovome arealu, budući da poznaju paroksitonezu utoliko što finalni slog nikada nije akcentovan; dok se etimološka oksitoneza čuva $u$ istočnomakedonskim i zapadnobugarskim govorima (cf. Alexander, op. cit.: 522). Idući dalje na sever, nailazimo na 
značajno slobodnije neetimološke paroksitoneze u prizrensko-timočkim i kosovsko-resavskim dijalektima. Paroksitoneza je u prizrensko-timočkim dijalektima veća što se više ide ka jugoistoku ove zone (ibid.: 50-51), dakle ka žarištu kontaktne zone sa albanskim i makedonskim jezikom, i uz to predstavlja i značajan sociolingvistički marker, budući da je povezana s ,kontaktom sa urbanom civilizacijom“ (ibid.: 53, 547-552), što takođe nije nevažan arealnolingvistički pokazatelj. Uz to, kao i u kosovsko-resavskom dijalektu, češće su retrakcije akcenta s otvorene nego sa zatvorene ultime, što predstavlja metričko ograničenje poput onoga u albanskome, ali još nisu i sasvim nezavisne od morfološke strukture reči. S druge strane, u kosovsko-resavskom, paroksitoneza je gramatički sasvim nezavisna i fonološki uzrokovana - ovde su sasvim fonologizovane retrakcije akcenta s kratke otvorene ultime; i uopšte, paroksitoneza postaje ,redovno obeležje u dijalektima jugozapadno, zapadno i severozapadno“ od prizrensko-timočke zone (ibid.: 521), uključujući zetsko-sandžačke govore. A odatle na zapad, nalazimo već i novoštokavsku metatoniju, koja je u ovim govorima u potpunosti automatska, u svim pozicijama.

Paralelno sa širenjem fonološke retrakcije akcenta s ultime, i dalje ka početku reči, na isti način se ovim arealom prostiru i metrička i morfonološka prozodijska obeležja, poput osetljivosti na slogovni kvantitet i morfološku strukturu reči. Albanski akcenat je, kako smo istakli iznad, bariton i u potpunosti osetljiv na morfološku strukturu reči, unutar koje je imobilno vezan za određeni slog (moru) osnove; kao i makedonski, koji je takođe imobilno vezan za granicu reči, budući da se uvek realizuje na penultimi ili antepenultimi, izuzev istočnomakedonskih govora, gde nailazimo i na paradigmatski mobilan akcenat. Dalje ka severozapadu, srećemo metrički ograničene paroksitoneze i u prizrensko-timočkim, kosovsko-resavskim i zetsko-sandžačkim govorima (češće sa otvorene i kratke nego sa metrički teške ultime, i sl.); a jednako i morfološki osetljive akcenatske obrasce, koji se postepeno gube $u$ prelazu ka novoštokavskim dijalektima.

Prizrensko-timočki slogovni akcenat je, naime, u značajno većoj meri vezan za morfološke klase nego što je to slučaj u zapadnijim štokavskim govorima (cf. ibid.: 519, 528 sqq., 541 sqq., 547, 552 sqq.); a u jugozapadnome delu ove dijalekatske zone baritoneza je široko rasprostanjeno obeležje - gotovo svi imenski i glagolski oblici su akcentovani na osnovi reči, dok su u istočnom tipu prizrensko-timočkih govora i u centralnom, južnomoravskom dijalektu, češći i etimološki akcenti na nastavcima 
(ibid.: 517-518). No, uopšte je, u mnogim gramatičkim kategorijama, u gotovo celoj prizrensko-timočkoj dijalekatskoj zoni, akcenat povučen sa etimološkog mesta na nastavku na osnovu reči (ibid.). I, ponovo kao u albanskom, pri tome postoje jasni znaci kvantitetske senzitivnosti slogovnog akcenta u jugoistočnom delu prizrensko-timočke zone, o čemu svedoče ustaljene etimološke oksitoneze na nastavcima dativa singulara animatnih imenica femininuma (sestré, snaé) i singulara aorista (idó, idé, nosí, pisá), koje se zapravo svode bilo na inicijalno dug slog (kao u kosovsko-resavskom, sestrê i sl.), bilo na slog zatvoren kodom sa $h>\emptyset$ (ibid.: 518-519).

\subsection{Jampsko-trohejski zakon i schwa albanicum}

Još jedno pitanje povezano s metričkom strukturom reči u albanskome predstavljaju i vokalske redukcije u neakcentovanim slogovima, te $\mathrm{s}$ njima povezan fonološki status vokala $\ddot{e}$ i tzv. jampsko-trohejski metrički zakon (Hayes 1985; 1995). Prema ovome zakonu, metrička organizacija akcenatskog kontrasta u dve univerzalne binarne stope, jamb ( . * ) i trohej (* . ), u artikulacionim bazama različitih jezika, ima za posledicu i razlike u segmentnoj organizaciji govornog izraza, tako što su jezici s jampskom metričkom stopom u principu skloni i duljenju akcentovanih i skraćivanju neakcentovanih slogova (tzv. jampsko duljenje), što nije slučaj i u jezicima s trohejskom metričkom stopom. Takve razlike, kako se smatra, proizilaze iz ekstralingvističkih ritmičkih principa, i mogu se, u vidu metričkog zakona, formulisati na sledeći način (ibid.: 80 sqq.):

a. Elementi koji se kontrastiraju intenzitetom prirodno formiraju grupe sa inicijalnom istaknutošću.

b. Elementi koji se kontrastiraju trajanjem prirodno formiraju grupe sa finalnom istaknutošću.

Drugim rečima, u trohejskim stopama ne postoje temporalni kontrasti, već oba dela ove binarne stope, bez obzira na njihovu relativnu istaknutost, imaju jednako trajanje. Trohej je, dakle, sa stanovišta euritmije, uvek simetrična stopa, jer se njegovi elementi ne kontrastiraju trajanjem; dok su jambovi, s druge strane, budući da se njihovi delovi upravo kontrastiraju varijacijama u trajanju, inherentno asimetrični. Albanski slogovni akcenat se, principijelno, slaže s ovako formulisanim jampsko-trohejskim zakonom, budući da se akcenatski kontrast u albanskome ostvaruje prvenstveno razlikama u intenzitetu, i prema opštem pravilu metričke organi- 
zacije reči u albanskome, zaista se u njemu i formiraju trohejske binarne

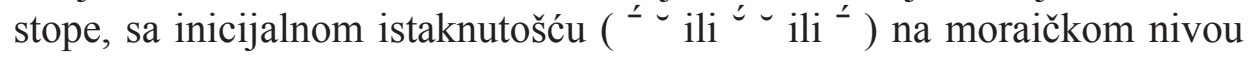
strukture $\left(\mu^{*} \mu\right)$, počev od desnog kraja osnove reči (Canalis, op. cit.). Međutim, albanski trohej jednako pokazuje i efekte duljenja i redukcije na segmentnoj ravni (v. u §2), koji su, prema iznad formulisanome zakonu, rezervisani za jampske stope.

U tom pogledu, uostalom, albanski ne predstavlja nikakav izuzetak. Kroslingvistički duljenje i skraćivanje, naime, nisu nepoznati segmentni procesi niti u tipološki različitim trohejskim sistemima (v. Revithiadou 2004), te bi klasični jampsko-trohejski zakon trebalo preformulisati tako da bolje odgovara jezičkoj empiriji (Crowhurst \& Olivares 2014). Nas ovde pak zanima to na koji način se odvijaju vokalske redukcije u albanskome trohejskom sistemu.

Stanišić (2004: 109; 2010: 162) razlikuje dve vrste vokalskih redukcija u jezicima balkanskog saveza, gde je redukcija vokala u albanskome $>\ddot{e}$ pretežno ,fiksirana“, tj. istorijska. Njeni efekti su danas vidljivi u segmentnoj strukturi, ali je njeno delovanje ograničeno; izuzev elizije finalnoga $\ddot{e}>\varnothing$ s kompenzacionim duljenjem. Međutim, to važi pre svega za toskijski dijalekat albanskoga, koji ne poznaje kvantitetske opozicije i sinkope neakcentovanog vokala $\ddot{e}$ kakve karakterišu gotovo sve gegijske govore (v. iznad). Prema tome, ,albansko-rumunski“ tip redukcije, koji je i u skladu s jampsko-trohejskim zakonom, predstavlja zapravo toskijsko-rumunsku arealnu paralelu, dok se u centralnome delu Balkana, u gegijskoj dijalekatskoj oblasti, s njom ne može na isti način računati. Gegijsko fonetsko duljenje akcentovanih vokala i distribuciona ograničenja vokalskog segmenta $\ddot{e}$ najbliže paralele imaju ne u rumunskom vokalizmu i u perifernim štokavskim govorima s istoka i sa zapada (Stanišić, ibid.), već upravo u, s jedne strane, vokalizmima centralnih balkanskih jezika i, s druge strane, vokalizmu centralnih štokavskih dijalekata koji poznaju isti tip akcenatski uslovljenih vokalskih redukcija (tipa vëlki, kòsca) - a s kojima gegijski dijalekat albanskoga, kao što je iznad rečeno, deli i neka zajednička obeležja i u konsonantizmu.

Albanski dijalekti se, prema tome, znatno razlikuju u pogledu prozodijskih sistema međusobno, i te se razlike ne iscrpljuju samo u vidu obeležja dužine i nazalizovanosti kod vokala; već u izvesnoj meri uključuju i samu prirodu slogovnog akcenta u dvama kompleksima dijalekata, način metričke organizacije reči i ritmička svojstva. Gegijski dijalekat albansko- 
ga pri tome predstavlja svojevrstan arealni „most“ između, s jedne strane, jezika tradicionalno shvaćenog balkanskoga jezičkog saveza na jugoistoku i, sa druge strane, štokavskih dijalekata, posebno onih u središnjoj (novo) štokavskoj zoni. Ovakav arealni položaj gegijskoga na Balkanu, svakako, nije i bez veze sa istorijskim okolnostima u široj društvenoj perspektivi; s time da upravo tuda prolazi nekadašnja osovina Otomanske imperije na Balkanu, s geografskim položajem Kosova, s time da se upravo ovde i u Bosni i Hercegovini Osmansko carstvo i najduže zadržalo, i sl.

\section{Zaključak}

Razmatrajući arealni kontekst baritoneze i paroksitoneze u jezicima centralnog i zapadnog Balkana, istaknuto je kako se i tradicionalni dijalekti albanskoga, u celini ili pojedinačno, odnose prema drugim balkanskim jezicima i štokavskome. U tom smislu, istaknut je centralni karakter gegijskog dijalekta albanskoga na Balkanu; koji usled specifičnog geografskog položaja i društvenoistorijskih okolnosti, i arealno predstavlja svojevrsnu sponu između jezika balkanskoga saveza na jugoistoku, kojima se pridružuje i toskijski dijalekat albanskoga, i srpskohrvatskih dijalekata na severu i severozapadu, sve do kompleksa bosanskohercegovačkih govora.

Pri tome, reč je o inovacijama na nivou segmentne ili suprasegmentne organizacije govora koje u različitoj meri zahvataju štokavsku i gegijsku albansku jezičku oblast, a sve od njih pokazuju najinovativniji razvoj u (novo)štokavskim dijalektima u Bosni i Hercegovini, s postepenim opadanjem k jugoistoku, do perifernih zona ovoga širokog zapadnobalkanskog fonološkog areala u toskijskome dijalektu i zapadnomakedonskim dijalektima, a uz ponovno nešto veći stepen inovativnosti u gegijskoj zoni, kao manjoj sekundarnoj žarišnoj oblasti:

1) svođenje palatalnih afrikatskih, odnosno eksplozivnih i afrikat-

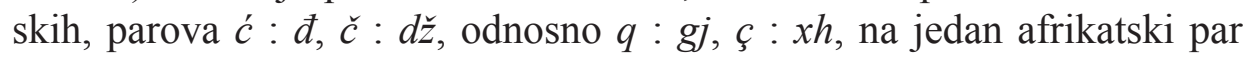
srednje umekšanosti;

2) ,konfesionalni apsurd“ $u$ artikulaciji velarnog odnosno glotalnog frikativa $h$ i njegovom funkcionalnom statusu u konsonantskom sistemu;

3) morfološka baritoneza, fonološka paroksitoneza, odnosno retrakcija akcenta sa otvorene ultime reči u turcizmima u gegijskome i novoštokavska metatonija;

4) sistem vokalskih redukcija u neakcentovanim slogovima, pove- 
zan s ritmičkom organizacijom i statusom vokalskog segmenta schwa u fonološkom sistemu;

i dr.

Neki su aspekti ovoga paralelizma (npr. sudbina palatala $g j>j$ između vokala) i ranije primećeni u albanološkim studijama, ali su pogrešno tumačeni kao čakavizmi u albanskome (v. Barić 1923). Reč je, međutim, o recentnijim pojavama u artikulacionoj bazi gegijskoga dijalekta, a ne o supstratsko-adstratskim arealnim odnosima - bilo da se, pri tome, tumače hipotezom o čakavskome ili štokavsko-makedonskom supstratu; koje najpre predstavljaju, kako izgleda, opštebalkanske sociolingvističke markere, relativno skorije formirane prema turskome kao zajedničkom sociolingvističkom superstratu (cf. i Ivić 1998b). U slučaju retrakcije i metričkog fiksiranja akcenta, odnosno vokalskih redukcija i ritmičke organizacije slogova, reč je ujedno i o istorijski ,dubokome“ gegijsko-srpskohrvatskom arealu koji, nezavisno od balkanizacije s jugoistoka, svedoči o bliskim jezičkim kontaktima ovih dveju govornih zajednica u dugom istorijskom periodu - od poznoantičkog metričkog fiksiranja akcenta u albanskome do i danas aktivne novoštokavske metatonije.

\section{Literatura}

AJETI, Idriz. „Për historinë e marrëdhënieve të hershme gjuhësore shqiptare-sllave.“ Studime filologjike 4 (1972): 83-94.

AleXAnder, Ronelle. Torlak Accentuation. München: Otto Sagner, 1975.

BABIĆ, Zrinka \& Višnja Josipović. „U potrazi za sustavnim prikazom hrvatskih naglasaka." Suvremena lingvistika 31/32 (1991): 37-58.

BABIĆ, Zrinka. "Accent Systems in Croatian Dialects." Autosegmental Studies on Pitch Accent. Ed. Harry van der Hulst \& Norval Smith, Dordrecht: Foris, 1988. 1-10.

BARIĆ, Henrik. „Ima li čakavskih pozajmica u arbanaskom?“ Arhiv za arbanasku starinu, jezik i etnologiju 1 (1923): 205-206.

BECI, Bahri. Fonetika e gjuhës shqipe. Tiranë: EDFA, 2004.

BECI, Bahri. Dialektet e shqipes dhe historia e formimit të tyre. Tiranë: Dituria, 2002.

BECI, Bahri. „Rreth tipareve karakteristike të dy dialekteve të shqipes.“ Studime filologjike 4 (1978): 53-87. 
BoJović, Jovan (ur.). Stanovništvo slovenskog porijekla u Albaniji. Titograd: Istorijski institut SR Crne Gore, 1991.

BozhoviQ, Gjorgje. „Theksi i fjalës në morfonologji të shqipes: teoria metrike dhe e optimalitetit.“ Seminari Ndërkombëtar për Gjuhën, Letërsinë dhe Kulturën Shqiptare 31:1 (2012): 143-152.

Bugarski, Ranko. Uvod u opštu lingvistiku. Beograd: Čigoja - XX vek, 1996.

ÇABEJ, Eqrem. „Kontributi i shqipes në formimin e lidhjes gjuhësore ballkanike." Studime gjuhësore IV. Prishtinë: Rilindja, 1987. 335-349.

CAnalis, Stefano. "To What Extent is Albanian Word Stress Predictable?" Proceedings of the XXXIII Incontro di grammatica generativa. Ed. Antonietta Bisetto \& Francesco Barbieri, Bologna: Università di Bologna, 2007. 1-14.

Crowhurst, Megan \& Amador Teodocio Olivares. "Beyond the Iambic-Trochaic Law: The Joint Influence of Duration and Intensity on the Perception of Rhythmic Speech." Phonology 31 (2014): 51-94.

Curtis, Michael. Slavic-Albanian Language Contact, Convergence, and Coexistence. Diss. Ohio State University, 2012.

DemiraJ, Shaban. Gjuha shqipe dhe historia e saj. Prishtinë: Rilindja, 1989.

DesnickajA, Agnija. Albanskij jazyk $i$ ego dialekty. Leningrad: Nauka, 1968.

DodI, Anastas. Fonetika dhe fonologjia e gjuhës shqipe. Tiranë: Akademia e Shkencave e Shqipërisë - Instituti i Gjuhësisë dhe i Letërsisë, 2004.

ELEzović, Gligorije. „Znatnije razlike između dve grupe govora u arbanaškom jeziku: gegiske i toskiske.“ Južnoslovenski filolog 18 (1949/50): 107-122.

GJINARI, Jorgji \& Gjovalin Shurtaj. Dialektologji. Tiranë: Universiteti i Tiranës - Fakulteti i Historisë dhe i Filologjisë, 2003.

GJINARI, Jorgji. „Zanoret hundore të gegërishtes dhe $\ddot{e}$-ja e theksuar e toskërishtes." Studime filologjike 3 (1981): 49-62.

GJINARI, Jorgji. Dialektologjia shqiptare. Prishtinë: Enti i teksteve dhe i mjeteve mësimore i Krahinës Socialiste Autonome të Kosovës, 1970.

Hayes, Bruce. Metrical Stress Theory: Principles and Case Studies. Chicago: University of Chicago Press, 1995. 
HaYes, Bruce. "Iambic and Trochaic Rhythm in Stress Rules." Proceedings of BLS 11: Parasesion on Poetics, Metrics, and Prosody. Ed. Mary Niepokuj et al., Berkeley: Berkeley Linguistic Society, 1985. 429-446.

Ismajli, Rexhep (red.). Shqipja dhe gjuhët e Ballkanit. Prishtinë: Akademia e Shkencave dhe e Arteve e Kosovës - Akademia e Shkencave e Shqipërisë, 2012.

IsMAJLI, Rexhep. „Rreth kuantitetit të zanoreve të theksuara të sistemit fonetik të shqipes." Gjurmime albanologjike 3 (1975): 57-61.

Ivić, Pavle \& Ilse Lehiste. O srpskohrvatskim akcentima. Sremski Karlovci - Novi Sad: Izdavačka knjižarnica Zorana Stojanovića, 2002.

Ivić, Pavle. „O fonološkim bliskostima između jezika i dijalekata na severnim obalama Mediterana." Rasprave, studije, članci: 1. O fonologiji. Sremski Karlovci - Novi Sad: Izdavačka knjižarnica Zorana Stojanovića, 1998a. 224-233.

Ivić, Pavle. „Dva glavna pravca razvoja konsonantizma u srpskohrvatskom jeziku." Rasprave, studije, članci: 1. O fonologiji. Sremski Karlovci - Novi Sad: Izdavačka knjižarnica Zorana Stojanovića, 1998b. 309-335.

KAŠIĆ, Zorka. „Segmentna i suprasegmentna organizovanost govora.“ Segmentna i suprasegmentna organizovanost govora $i$ poremećaji fluentnosti. Ur. Slavica Golubović i Zorka Kašić, Beograd: Društvo defektologa Jugoslavije, 2000. 9-62.

KRISTAL, Dejvid. Enciklopedijski rečnik moderne lingvistike. Beograd: Nolit, 1988.

Laver, John. "The Concept of Articulatory Settings: An Historical Survey." Historiographia Linguistica 5:1/2 (1978): 1-14.

Lehiste, Ilse \& Pavle Ivić. Prozodija reči $i$ rečenice u srpskohrvatskom jeziku. Sremski Karlovci - Novi Sad: Izdavačka knjižarnica Zorana Stojanovića, 1996.

Malmberg, Bertil. Fonetika. Sarajevo: Svjetlost, 1974.

Miklosich, Franz. Albanische Forschungen I. Wien: Kaiserlich-Königliche Hof- und Staatsdruckerei, 1870.

Miletić, Branko. Osnovi fonetike srpskoga jezika. Beograd: Znanje, 1952.

Mladenović, Radivoje. „Mesto akcenta imenica na jugozapadu Kosova i Metohije.“ Južnoslovenski filolog 56 (2000): 699-725. 
Moosmüller, Sylvia \& Theodor Granser. "The Spread of Standard Albanian: An Illustration Based on an Analysis of Vowels." Language Variation and Change 18 (2006): 121-140.

OMARI, Anila. Marrëdhëniet gjuhësore shqiptaro-serbe. Tiranë: Qendra e Studimeve Albanologjike - Instituti i Gjuhësisë dhe i Letërsisë, 2012.

Orel, Vladimir. A Concise Historical Grammar of the Albanian Language: Reconstruction of Proto-Albanian. Leiden - Boston - Köln: Brill, 2000.

PECO, Asim. „Izgovor afrikata u bosansko-hercegovačkim govorima.“ Zbornik Matice srpske za filologiju i lingvistiku 42 (1999): 356-382.

PECo, Asim. „Jedan pogled na ikavsko-šćakavske govore zapadne Bosne.“ Proučavanje bosansko-hercegovačkih govora: dosadašnji rezultati, potrebe i perspektive. Ur. Milan Šipka, Sarajevo: Institut za jezik i književnost, 1974. 49-58.

PižUricA, Mato. „Tragovi međujezičkih dodira u govorima Crne Gore.“ Crnogorski govori: rezultati dosadašnjih ispitivanja $i$ dalji rad na njihovom proučavanju. Ur. Jevto Milović, Titograd: Crnogorska akademija nauka i umjetnosti, 1984. 83-95.

PolÁk, Václav. „Albánci a Slované (vznik a počáty dnešnich nárečních variant albánskich). “ Časopis pro moderni filologii 39:2/3 (1957): 85-89.

Popović, Ivan. „Slaven und Albaner in Albanien und Montenegro: Zum Problem der slavisch-albanischen Sprachchronologie." Zeitschrift für slavische Philologie 26 (1958): 301-324.

REMETIĆ, Slobodan. „Srpski narodni govori Kosova i Metohije u svetlu međujezičke i međudijalekatske interferencije." Južnoslovenski filo$\log 60$ (2004): 113-123.

Revithiadou, Anthi. "The Iambic/Trochaic Law Revisited: Lengthening and Shortening in Trochaic Systems." Leiden Papers in Linguistics 1:1 (2004): 37-62.

Simić, Radoje \& Branislav Ostojić. Osnovi fonologije srpskog književnog jezika. Beograd: Univerzitet u Beogradu, 1996.

Sкок, Petar. "Slave et albanais." Arhiv za arbanasku starinu, jezik $i$ etnologiju 2 (1924): 107-126.

STANIŠIĆ, Vanja. „Srpsko-albanski fonološki odnosi između uticaja i areal- 
nog jedinstva." Teorija dijahronijske lingvistike i proučavanje slovenskih jezika. Ur. Jasmina Grković-Mejdžor \& Milorad Radovanović, Beograd: Srpska akademija nauka i umetnosti, 2010. 159-176.

STANIŠIĆ, Vanja. „O emancipaciji mekoće u slovenskim i balkanskim jezicima.“ Probleme de filologie slavă 15 (2007): 319-329.

STANIŠIĆ, Vanja. „O palatalnoj korelaciji suglasnika u slovenskim i balkanskim jezicima." Probleme de filologie slavă 14 (2006): 175-188.

Stanišić, Vanja. „Povodom foneme /ü/ u srpskim govorima na Kosovu i Metohiji.“ Kosovsko-metohijski zbornik 3 (2005): 21-32.

STANIŠIĆ, Vanja. „Srpsko-albanski jezički dodiri i dva tipa fonoloških sistema u balkanskim jezicima.“ Balcanica 34 (2004): 105-117.

STANIŠIĆ, Vanja. Srpsko-albanski jezički odnosi. Beograd: Balkanološki institut SANU, 1995.

ŠIPKA, Milan (ur.). Proučavanje bosansko-hercegovačkih govora: dosadašnji rezultati, potrebe $i$ perspektive. Sarajevo: Institut za jezik i književnost, 1974.

Đorđe Božović

\section{Summary}

\section{ARTICULATORY SETTINGS IN CONTACT: SOCIOPHONOLOGICAL ASPECTS}

The paper details an analysis of the Albanian phonemics, prosody and metrics in an areal perspective, with a special emphasis on its relations with South Slavic, and Serbo-Croatian in particular. In addition to an extensive previous research on the Albanian-Slavic contacts in phonetics and dialectology, a novel series of common phonological features in Geg Albanian and the Serbo-Croatian dialects of Bosnia and Herzegovina is identified, both in the segmental as well as the suprasegmental domains: 1) the realization of palatal affricates; 2) the realization of the glottal fricative; 3 ) the position of stress, with retraction from the word boundary and formation of trochaic metrical feet; 4) the principles of unstressed vowel reduction, resulting from the aforementioned system of word prosody. Contrary to the existing hypotheses, which relate the Albanian-South Slavic phonological contacts to the early medieval period, when a Slavic substrate or adstrate existed in Northern Albanian, it is argued that these areal features span the entire common historical period of the two languages, to this day. Additionally, it is argued that Turkish has had to have an important rôle in the articulatory setting of 
palatal affricates and the glottal fricative in the urban vernaculars of Geg Albanian and of the Bosnian Muslims during the 19th century, given its high social status as the prestige idiom and its sociolinguistic functions in the process of identity construction during the era of Nationalism.

Keywords: palatal affricates, glottal fricative, stress retraction, vowel quantity and quality, Albanian language, Balkan Sprachbund. 